\title{
Development of Biobased Poly(Lactic Acid)/Epoxidized Natural Rubber Blends Processed by Electrospinning: Morphological, Structural and Thermal Properties
}

\author{
Jaqueline G. L. Cosme, Vanessa M. Silva, Regina R. C. Nunes, Paulo H. S. Picciani \\ Institute of Macromolecules, Federal University of Rio de Janeiro, Rio de Janeiro, Brazil \\ Email: jaqueglcima@gmail.com
}

Received 17 March 2016; accepted 21 April 2016; published 27 April 2016

Copyright (C) 2016 by authors and Scientific Research Publishing Inc.

This work is licensed under the Creative Commons Attribution International License (CC BY).

http://creativecommons.org/licenses/by/4.0/

(c) (i) Open Access

\begin{abstract}
This article reports the production of electrospun fibers from blends of poly(lactic acid) (PLA) and epoxidized natural rubber (ENR) solutions. The produced fibers were characterized by scanning electron microscopy (SEM), Fourier transform infrared spectroscopy (FTIR), differential scanning calorimetry (DSC), thermogravimetric analysis (TGA) and dynamic mechanical analysis (DMA). SEM images showed the reduction in fiber size with ENR content of up to $25 \%$ in the mixture PLA/ENR. FTIR analysis revealed a possible interaction between carboxylic group of PLA and epoxi group of ENR. Thermal analysis showed the increase of the crystallinity fraction with ENR content and a decrease in thermal stability of eletrospun mats with the addition of ENR. The dynamic mechanical properties showed an enhancement of the stiffness of PLA/ENR blends with the increase of ENR content, which can support the production of interesting materials for tissue engineering based on renewable and biocompatible polymers. The reported properties indicate the possibility to use such fiber mats as potential materials in tissue engineering.
\end{abstract}

\section{Keywords}

Poly(Lactic Acid), Epoxidized Natural Rubber, Electrospinning, Biocompatible Polymers, Polymer Blend 


\section{Introduction}

Electrospinning has been received considerable attention due to its high efficiency in producing nonwoven mats from fibers that are micro or sub-micron in diameter [1]-[3]. Such mats are effective in providing large surface area-to-volume and length-to-diameter ratios, thereby being used in numerous applications like tissue engineering scaffolds [4]-[7], sensors [8], protective clothing [9], separation membranes [10], wound healing [11], release of drugs [12], etc.

In the electrospinning process a polymer solution is usually pumped through a metal capillary, acting as an electrode to which a high intensity electric field is applied. Initially, the solution is maintained by its surface tension in the form of a drop at the end of the capillary. As the electric forces overcome the surface tension of the solution, a polymeric jet is generated from the surface of the droplet and travels towards to the grounded target. During the trajectory of the jet, the solvent evaporates and consequently polymer fibers can be collected [13][15].

Recently, the use of biodegradable and biocompatible polymers has become increasingly important due to their fascinating characteristics such as natural abundance, low costs, and wide range of applications [16]. Moreover, biodegradable polymers and their blends have been concerned to overcome the environmental issues which arise from the nondegradable polymers. Electrospinning has been applied in producing numerous biodegradable polymers mats for biomedical applications, such as poly(lactic acid) (PLA) [17] [18], poly( $\varepsilon$-caprolactone) (PCL) [19], poly(glycolic acid) (PGA) [20], poly(lactide-co-glycolide) (PLGA) [21].

This work reports the production of a new biomaterial based on electrospun PLA/NR blends which combine the properties of a very well-established polymer as PLA with those of NR, which has been cited as an interesting biomaterial due to its recently discovered biological properties [22] [23]. In this approach, important properties of PLA as solubility in common solvents, biodegradability, good mechanical properties, and biocompatibility [24] [25] are combined with those of natural rubber (NR) as recently demonstrated applications in stimulating wound healing, angiogenesis, and tissue regeneration [22] [23]. The electrospinning method is chosen due to its capability of providing membranes with a very large surface area which can offer ideal space for cell adhesion and proliferation, also the porous structures can provide windows for oxygen and nutrients transfer when the scaffolds are used in tissue engineering applications.

A previous work reported the fabrication of a biocompatible material of PCL/NR blend by electrospinning [23] with potential application in tissue engineering. Authors found out membranes with high porosity and a decreasing in fiber diameter with the increase of NR content in the blends.

However, difference in electrical polarity between these PLA and NR may hamper the compatibility between two polymers. As NR is an unsaturated polymer with a large number of double bonds in the backbones that are reactive, epoxidized natural rubber (ENR) can be prepared in latex stage by reacting natural rubber with peroxide [26] [27] forming epoxy groups of ENR that would improve the polarity of rubber and hence promoting compatibility with PLA. Nghia et al. [28] investigated the compatibility of the ENR/PLA solution blend; they concluded that the reaction occurred between the epoxy groups of ENR and the ester groups of PLA. In this way, a new biomaterial based on PLA/ENR electrospun blends was obtained by electrospinning approach and the effect of ENR content on the blends was studied with the help of characterization techniques such as scanning electronic microscopy (SEM), Fourier transform infrared spectroscopy (FTIR), differential scanning calorimetry (DSC), thermogravimetric analysis (TGA) and dynamic mechanical analysis (DMA).

\section{Experimental}

\subsection{Materials}

PLA (Poly(lactic acid) (polylactide resin 4042D) with a molecular weight of 66,000 g/mol was acquired from Nature Works LLC (Minnetonka, MN). Natural rubber latex (solid content 61.9\%) was kindly supplied by Teadit Indústria e Comércio Ltda. (Rio de Janeiro, Brazil). Chloroform, formic acid (98\% purity), hydrogen peroxide (30\% - 32\%), sodium carbonate and ethanol were purchased from Sigma-Aldrich (São Paulo, Brazil). Ultranex NP 95 (nonylphenylpoly(ethylene glycol)) of 9.5 EO (number of ethylene oxide molecules) was supplied by Oxiteno S. A. Indústria e Comércio (São Paulo, Brazil). The polymers and all chemicals were used without further purification. 


\subsection{Epoxidation of Natural Rubber in the Latex}

Epoxidized natural rubber (ENR), containing $20 \mathrm{~mol} \%$ epoxy groups, was obtained as described elsewhere [26]. Briefly, NR latex was diluted to 20\% DRC (dry rubber content) and stabilized with 5 phr of Ultranex NP 95. The epoxidation reaction was carried out in a thermostatic bath to control the reaction temperature. Formic acid was added and the temperature was raised to $40^{\circ} \mathrm{C}$. Subsequently, the hydrogen peroxide solution was added and the reaction medium was then kept at $70^{\circ} \mathrm{C}$ for $8 \mathrm{~h}$. After epoxidation, the reaction medium was neutralized with $10 \%$ aqueous sodium carbonate solution. The product was coagulated in ethanol and dried.

\subsection{Samples Preparation}

Polymer solutions were previously prepared at room temperature under magnetic stirring. PLA/ENR (a blend polymer consisting of PLA and ENR in the ratios 100/0, 90/10, 75/25 and 50/50 wt. \%) solutions were prepared by dissolving in chloroform to obtain a $15 \% \mathrm{w} / \mathrm{v}$ polymer concentration. The solution was then poured in a $5 \mathrm{~mL}$ BD Luer-Lok tip plastic syringe having a stainless-steel needle with 25 gauge $90^{\circ}$ blunt end. The electrospinning was carried out by means of a high voltage power supply (Model PS/FC60P02.0-11, Glassman High Voltage Inc., NJ, USA) and a digitally controlled syringe pump (Model 100, KD Scientific Inc., Holliston, MA) in the following conditions: flow rate $0.5 \mathrm{~mL} / \mathrm{h}$ and applied voltage $17.5 \mathrm{kV}$. Electrospun mats were collected onto a metallic plate colector grounded covered with aluminum foil at $12 \mathrm{~cm}$ from the blunt tip of the capillary.

\subsection{Characterization}

Morphology of PLA and PLA/ENR electrospun mats was obtained by scanning electron microscopy (SEM) in a JEOL JSM-5300 microscope at an acceleration voltage of $18 \mathrm{kV}$. Samples were previously sputter-coated with gold. Fibers diameters were analyzed from the images with the help of Image ${ }^{\circledR}$ software.

Fourier transform infrared (FTIR) spectra of PLA and the blends were obtained using VARIAN spectrometer (model FTIR 3100) over the wave number range of $4000-500 \mathrm{~cm}^{-1}$, at an accumulation of 32 scans with a resolution of $4 \mathrm{~cm}^{-1}$.

Thermal properties of PLA and PLA/ENR blends were measured by a differential scanning calorimeter (Q1000, TA Instruments). Samples of 6 - $7 \mathrm{mg}$ were taken in an aluminum pan and sealed tightly with an aluminum cover. The samples were first cooled to $-80^{\circ} \mathrm{C}$ and then heated to $180^{\circ} \mathrm{C}$ at a rate of $10^{\circ} \mathrm{C} / \mathrm{min}$ under a nitrogen atmosphere. The glass transition temperature, cold crystallization and melting temperatures denoted as $\mathrm{T}_{\mathrm{g}}, \mathrm{T}_{\mathrm{c}}$ and $\mathrm{T}_{\mathrm{m}}$, respectively, were obtained from the DSC curves. The crystallinity $(\alpha)$ of PLA in the PLA/ENR blend was evaluated from the DSC data by using the Equation (1) [29]:

$$
\chi(\%)=\frac{\Delta H_{m}-\Delta H_{c c}}{\Delta H_{m}^{\circ} \cdot\left(1-\phi_{E N R}\right)} \times 100
$$

where $\Delta H_{m}, \Delta H_{c c}$ and $\Delta H_{m}^{\circ}$ are respectively the enthalpies of cold crystallization, melting and melting for $100 \%$ crystalline PLA. The value used for $\Delta H_{m}^{\circ}$ is $93.1 \mathrm{~J} / \mathrm{g}$ [30]. $\phi_{\mathrm{ENR}}$ is the content of ENR in PLA/ENR blends.

The thermal stability of the samples (about $4 \mathrm{mg}$ ) was investigated with a TGA instrument (TA-Q600) under nitrogen atmosphere from $30^{\circ} \mathrm{C}$ to $700^{\circ} \mathrm{C}$ at a heating rate of $10^{\circ} \mathrm{C} / \mathrm{min}$.

Dynamic mechanical analysis (DMA) was performed using a DMA Q800, TA Instrument. Specimens were analyzed in tensile mode at a constant frequency of $1 \mathrm{~Hz}$, a strain of $0.01 \%$, and a temperature ranging from $-80^{\circ} \mathrm{C}$ to $100^{\circ} \mathrm{C}$ at a heating rate of $2^{\circ} \mathrm{C} / \mathrm{min}$.

\section{Results and Discussion}

\subsection{Morphology of the Electrospun Mats}

In order to study the effect of ENR on the morphology of electrospun PLA/ENR fibers, blends with PLA/ENR ratios of (0/100), (90/10), (75/25) and (50/50) were investigated. Figure 1 shows SEM images of the electrospun PLA/ENR blend mats at 1000x magnification. The average diameter values of the fibers were determined based on 50 measurements of individual fibers randomly chosen from each SEM image with the same magnification. As shown in Figures 1(a)-(d), when the PLA/ENR ratios were 100/0, 90/10, 75/25 and 50/50, the diameters of electrospun fibers were 1889 ( \pm 327$), 1474$ ( \pm 432$), 1241( \pm 229), 858( \pm 198)$, e $2671( \pm 359) \mathrm{nm}$, respectively. 

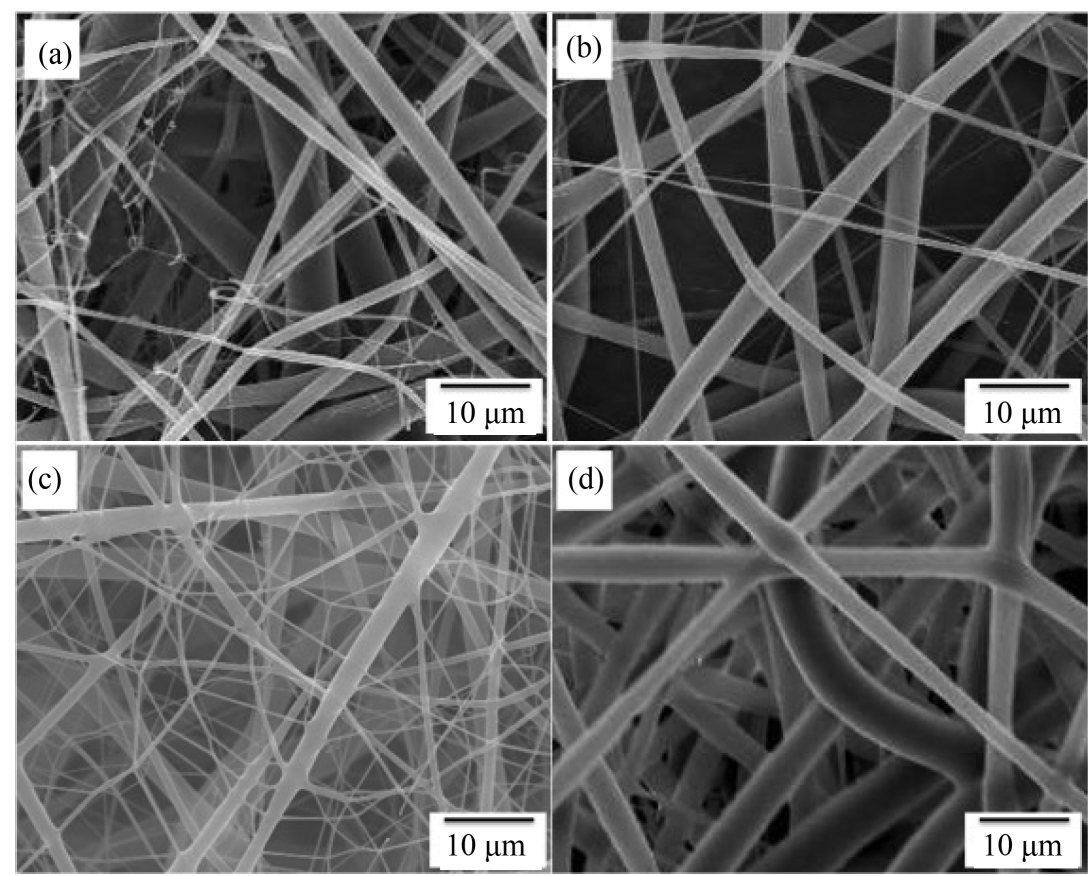

Figure 1. SEM images of (a) 100/0, (b) 90/10, (c) 75/25, (d) 50/50 PLA/ENR electrospun blends with magnification of $1000 \times$.

Note that all of these fibers had smooth surface, and the mats contained no beaded-fibers. It can be seen that increasing the ENR content up to 25 wt.\% resulted in the decrement of the fiber size. Costa et al. [25] reported similar observation in which the increase in NR concentrations resulted in a reduction of fiber diameters of PCL/NR electrospun blends, also enhancing the total surface area and porosity of membranes.

\subsection{Fourrier Transform Infrared Spectroscopy-FTIR}

Figure 2 exhibits the FTIR spectra in the region $4000-500 \mathrm{~cm}^{-1}$ of ENR, PLA and PLA/ENR blends. From the FTIR spectra of ENR, the peaks at 2961, 2917, and $2854 \mathrm{~cm}^{-1}$ are attributed to C-H stretching from $-\mathrm{CH}_{2}$ group. The absorption bands at 1448 and $1377 \mathrm{~cm}^{-1}$ are originated from $\mathrm{C}-\mathrm{H}$ stretching from $-\mathrm{CH}_{3}$ group. The characteristic peaks at $870 \mathrm{~cm}^{-1}$ and $836 \mathrm{~cm}^{-1}$ are assigned to the asymmetric and symmetric vibration of the epoxy ring [31]. In the case of PLA, the absorptions at 1450, 1360 and $1267 \mathrm{~cm}^{-1}$ are attributed to C-H deformation from $-\mathrm{CH}_{2}$. The bands at 1182, 1128, 1084 and $1044 \mathrm{~cm}^{-1}$ are originated from C-O-C bending vibrations [32]. The bands at 869 and 755 are due to C-C stretching vibrations. The absorption peak at $1750 \mathrm{~cm}^{-1}$ is attributed to the stretching vibration of carbonyl groups of PLA [31]. Figure 2 also shows that the peaks of the blends consist of PLA and ENR characteristic peaks. The peak position at $1750 \mathrm{~cm}^{-1}$ of PLA shifted to higher wave numbers in the blends as the ENR content increased, which suggests some interaction between the carboxylic end group of PLA chains and oxirane group of ENR.

\subsection{Thermal Properties of PLA/ENR Electrospun Blends}

Differential scanning calorimetry was used to investigate the effect of the ENR addition on the thermal properties of PLA. The thermal properties of PLA and PLA/ENR electrospun blends are presented in Figure 3 and the corresponding data are summarized in Table 1. Glass transition temperature $\left(\mathrm{T}_{\mathrm{g}}\right)$ is obtained from the inflection of glass transition based by the second heating scan. The $T_{g}$ of PLA/ENR blends is located at the almost same temperature around $57^{\circ} \mathrm{C}$, indicating that there is no evident effect on the $\mathrm{T}_{\mathrm{g}}$ of PLA by the addition of ENR. This same behavior was observed when Zhang et al. [27] studied the thermal properties of PLA/ENR by melt blending. Bitinis et al. [33] also stated that there were no changes in the glass transition temperature of PLA with the NR content.

As PLA used in this work was crystalline poly (L-lactide), the effect of the incorporation of the epoxidized 


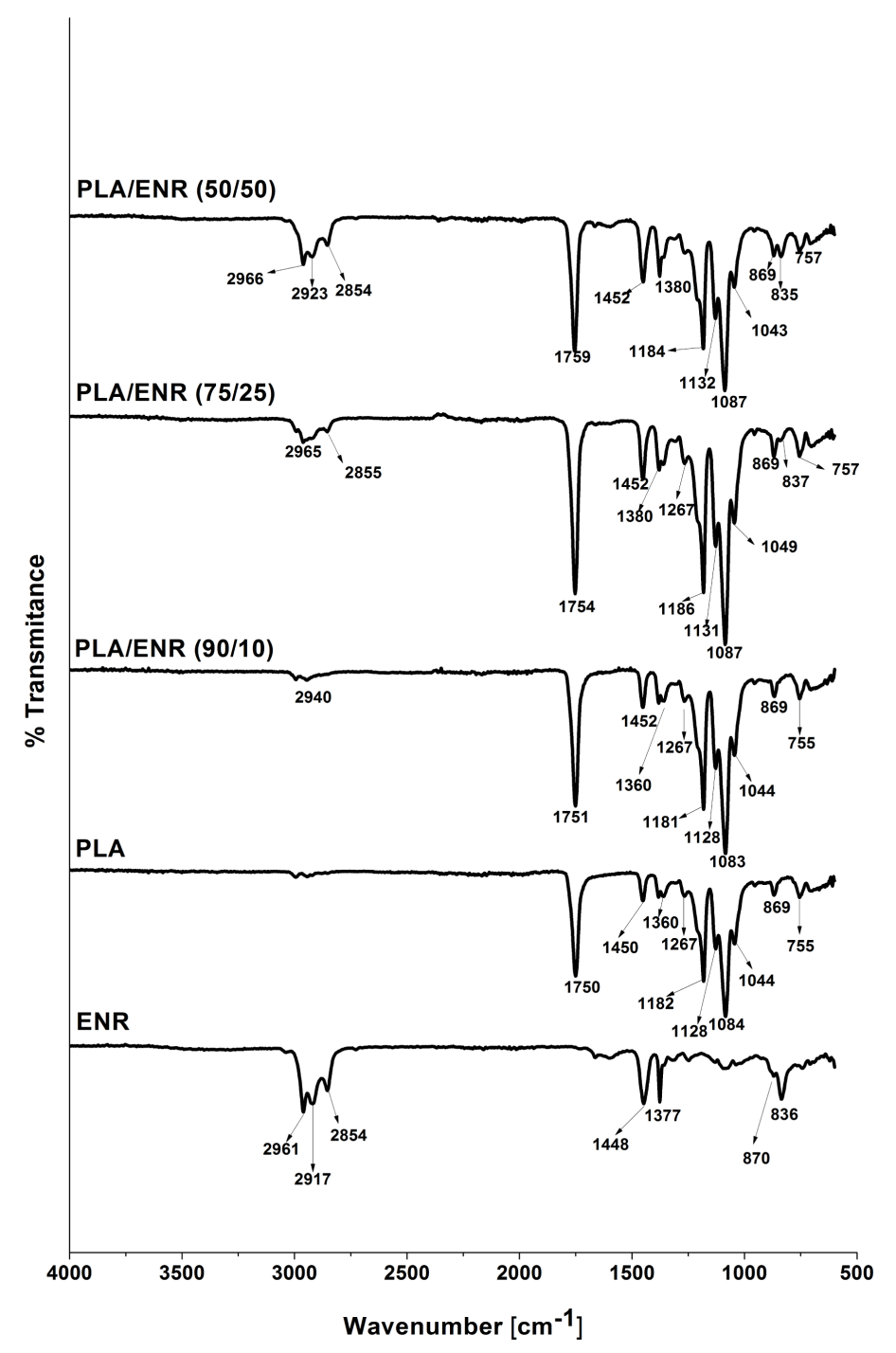

Figure 2. FTIR spectra of PLA, ENR and PLA/ENR electrospun blends.

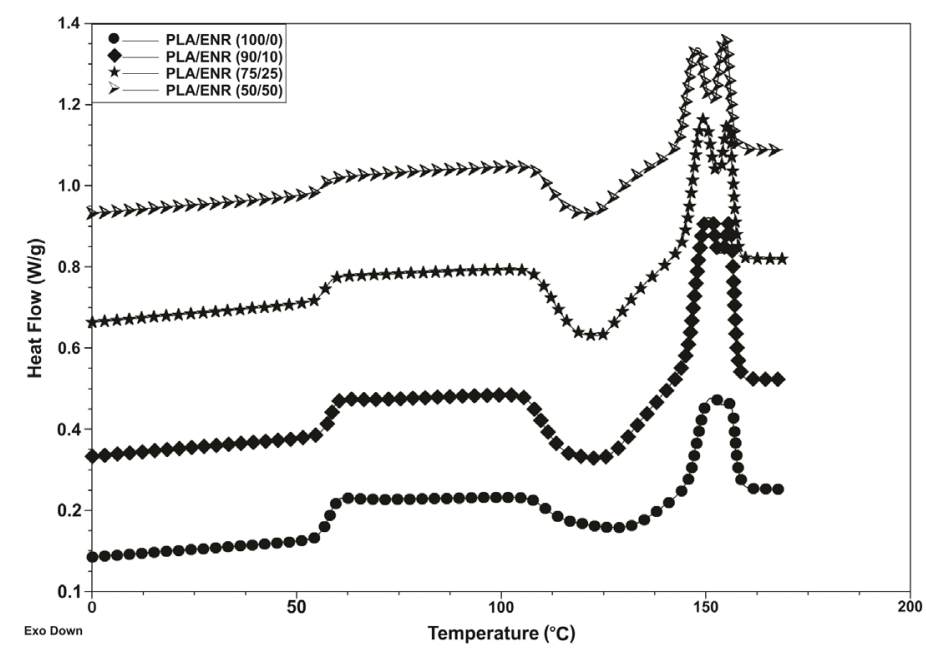

Figure 3. DSC thermograms of PLA/ENR electrospun blends. 
natural rubber in the degree of crystallinity of PLA was studied. As expected electrospun PLA mats develops lower crystallinity values [34]. Thermal data in Table 1 show an enhancement on the degree of crystallinity of the PLA with the ENR content. Kaavessina et al. [35] studied the crystallization behavior of poly (lactic acid)/ elastomer blends. According to the authors, elastomers may act as diluent agent on the crystallization process of poly (lactic acid) by giving the extra mobility of its chains to form crystal. This is especially significant for electrospun samples during the fast solvent evaporation and polymer solidification, which favors the crystal growth formation and increasing in the degree of crystallinity. These results suggest that the blends started to crystallize at lower temperatures than neat PLA, which is an indication that the presence of ENR can act as nucleating agent on the crystallization of PLA [36] and also indicates that ENR induced less perfect PLA crystals under the rate used in this heating process. Similar findings was reported by Wahit et al. [37] in which nucleating effect led to decrease in $T_{c}$ and increase in the crystallinity of the PLA/ENR blends.

Melting endotherms of PLA and PLA/ENR blends are shown in Figure 3 and Table 1. It can be seen that the melting temperature decreases with the incorporation of ENR. Besides, all the samples revealed two melting peaks. Sarasua et al. [38] have explained the double-peak melting point of PLA in their previous report. They stated that the melting peak at higher temperature corresponded to more perfect crystalline form than that at lower temperature. Double melting endotherms can be attributed to the melt recrystallization mechanism of PLA, which is originated from PLA crystal growth. The less perfect crystals ( $\alpha$ '-form crystal) of PLA have sufficient time to melt and reorganize into perfect crystals ( $\alpha$-form crystals) before giving a second endotherm at higher temperature [38]-[40]. The presence of ENR may retard the formation of perfect crystallites of PLA, thus, double-melting peak can be associated with formation of different lamellae thickness and the melt-recrystallization mechanism [32].

Thermal stability of PLA and PLA/ENR electrospun blends determined by thermogravimetric analysis is shown in Table 2. PLA and PLA/ENR sample with $10 \mathrm{wt} . \%$ of ENR presented an one-stage weight loss during thermal decomposition. The addition of more than 10 wt.\% of ENR resulted two stages of degradation which is associated with different polymer phases of the blends. Noticeably, the thermal stability of the blends decreased as ENR content increased in the blends. Wahit et al. [36] have studied the thermal stability of PLA/ENR blends in their previous report. They attributed the reduction of the thermal stability to the oxidation of the epoxide groups at high temperatures. Moreover, ENR can act as an auto oxidant and initiate a free radical reaction. Subsequently, the free radicals generated start the oxidation of the PLA in the blend.

\subsection{Dynamic Mechanical Analysis-DMA}

Viscoelastic behavior of a polymer blend under dynamic conditions can reveal important information on microstructure and interfacial interactions of the blends [41]. Storage moduli of PLA/ENR blends over a wide temperature range of $-80^{\circ} \mathrm{C}$ to $100^{\circ} \mathrm{C}$ is shown in Figure 4. As one can see, the storage modulus (E') of the

Table 1. Thermal characteristics of PLA/ENR electrospun blends recorded by DSC.

\begin{tabular}{cccccc}
\hline $\begin{array}{c}\text { Samples } \\
\text { PLA/ENR }\end{array}$ & $\mathrm{T}_{\mathrm{g}}\left[{ }^{\circ} \mathrm{C}\right]$ & $\mathrm{T}_{\mathrm{m} 1}\left[{ }^{\circ} \mathrm{C}\right]$ & $\mathrm{T}_{\mathrm{m} 2}\left[{ }^{\circ} \mathrm{C}\right]$ & $\mathrm{T}_{\mathrm{c}}\left[{ }^{\circ} \mathrm{C}\right]$ & $\mathrm{X}[\%]$ \\
\hline $100 / 0$ & 57.46 & 151.23 & 155.95 & 127.92 & 3.4 \\
$90 / 10$ & 57.72 & 150.25 & 155.62 & 123.35 & 6.5 \\
$75 / 25$ & 57.41 & 149.45 & 155.49 & 95.04 & 8.1 \\
$50 / 50$ & 56.71 & 147.84 & 154.60 & 121.83 & 8.6 \\
\hline
\end{tabular}

Table 2. Decomposition temperatures for PLA/ENR electrospun blends obtained from TGA curves.

\begin{tabular}{ccccc}
\hline \multirow{2}{*}{$\begin{array}{c}\text { Samples } \\
\text { (PLA/ENR) }\end{array}$} & \multicolumn{2}{c}{$\mathrm{TG}$} & $\mathrm{T}_{\max 1}\left[{ }^{\circ} \mathrm{C}\right]$ & $\mathrm{T}_{\max 1}\left[{ }^{\circ} \mathrm{C}\right]$ \\
\cline { 2 - 5 } & $\mathrm{T}_{\text {onset1 }}\left[{ }^{\circ} \mathrm{C}\right]$ & $\mathrm{T}_{\text {onset2 }}\left[{ }^{\circ} \mathrm{C}\right]$ & 351.37 & - \\
$100 / 0$ & 326.91 & - & 336.70 & 362.75 \\
$90 / 10$ & 303.97 & - & 314.84 & 377.22 \\
$75 / 25$ & 285.43 & 362.12 & 284.75 & - \\
$50 / 50$ & 257.33 & 358.54 & & \\
\hline
\end{tabular}




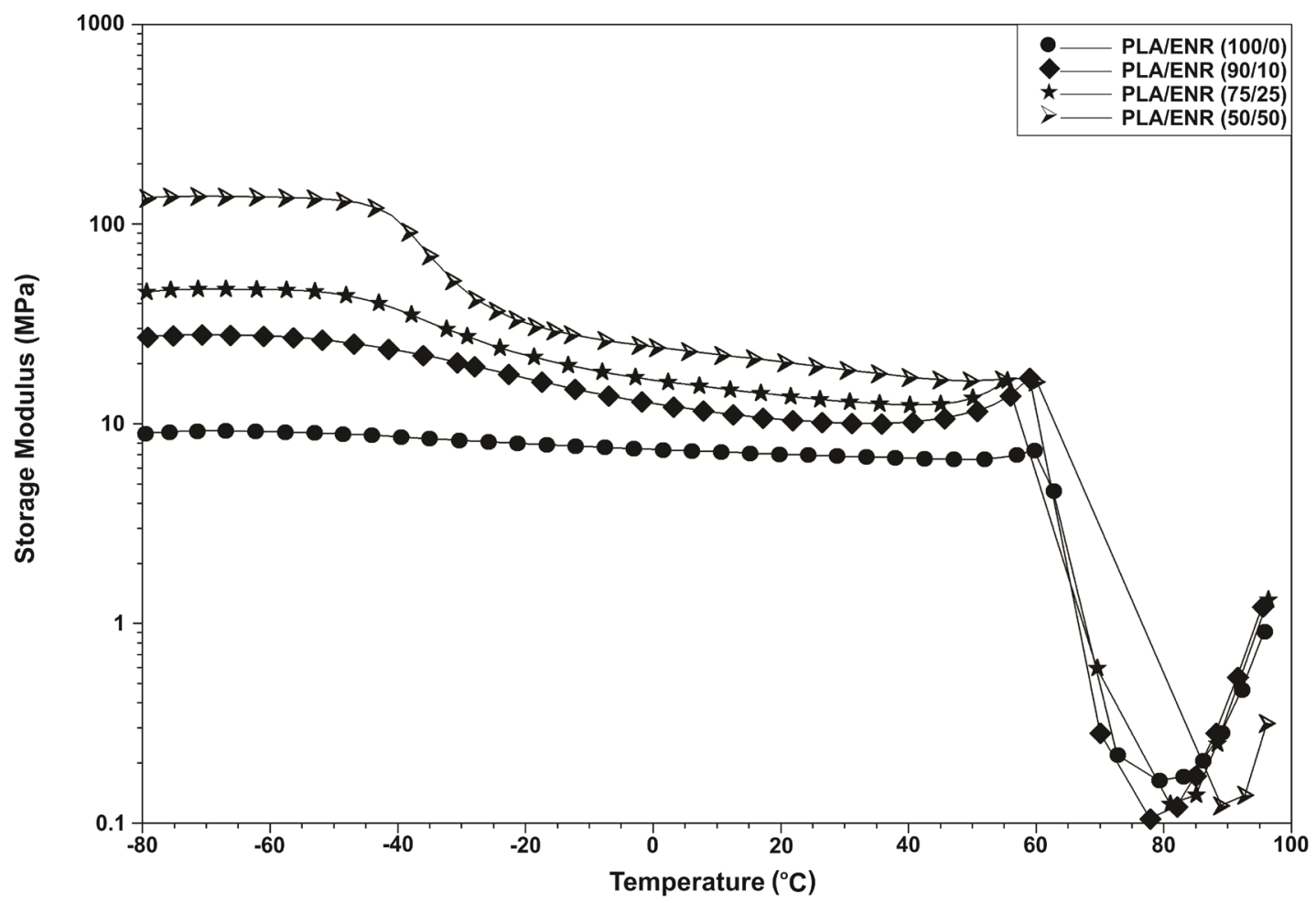

Figure 4. Storage Modulus (E’) versus temperature for PLA/ENR electrospun blends.

blends had an initial decrement (around $-40^{\circ} \mathrm{C}$ ) as consequence of the segmental mobility $\left(\mathrm{T}_{\mathrm{g}}\right.$ ) of ENR chains and then dropped dramatically after the $\mathrm{T}_{\mathrm{g}}$ of PLA, which resulted from the softening or segmental mobility of PLA molecules. Interestingly, the addition of ENR to PLA increase E' values with the ENR content. This effect is closely related to the interaction between the epoxy groups of ENR and carbonyl groups of PLA, which can produce a percolation network which prevents the PLA chains from free moving, and leads to the increase of storage modulus [27].

Moreover, the enhancement of storage modulus can be related to the increase in the stiffness ( $\tan \delta$ peak increased with the ENR content, see Figure 5) as consequence of increased crystallinity fraction confirmed by DSC data findings. Figure 5 presents the temperature dependences of $\tan \delta$ of PLA/ENR electrospun blends. Tan delta peaks of all types were remarkably observed in the region $70^{\circ} \mathrm{C}$ with $\mathrm{T}_{\mathrm{g}}$ values of $69.20^{\circ} \mathrm{C}(0 / 100), 70.04^{\circ} \mathrm{C}$ (90/10), $69.45^{\circ} \mathrm{C}(75 / 25)$ and $70.04^{\circ} \mathrm{C}(50 / 50)$. Such a result supports the findings from the DSC data that the $\mathrm{T}_{\mathrm{g}}$ values of PLA/ENR blends are located at the almost same temperature, indicating that there is no evident effect on the $\mathrm{T}_{\mathrm{g}}$ of PLA by the addition of ENR.

\section{Conclusion}

In this work polymer compositions with poly(lactic acid) (PLA) and epoxidized natural rubber (ENR) were processed by electrospinning. The effect of ENR on the morphological, structural, thermal and dynamic mechanical properties of the blends was found to be pronounceable. SEM results revealed that mats with micrometer- and submicrometer-sized fibers were obtained with no bead structures and the addition of $25 \mathrm{wt} \%$ of ENR content reduced the fiber diameters. FTIR studies showed some level of interaction between carboxylic end group of PLA chains and epoxi group of ENR. Results of thermal properties showed that the increasing in ENR content surprisingly caused the increase in crystallinity fraction. Further, dynamic mechanical properties showed that the molecular interaction between the epoxy groups of ENR and carbonyl groups of PLA, and the increased crystallinity may have been responsible by the enhancement of the rigidity and the storage modulus. The obtained results showed that electrospinning was suitable for producing PLA/ENR blends suitable for biomedical applications such as tissue engineering. Considering the importance of developing new biomaterials 


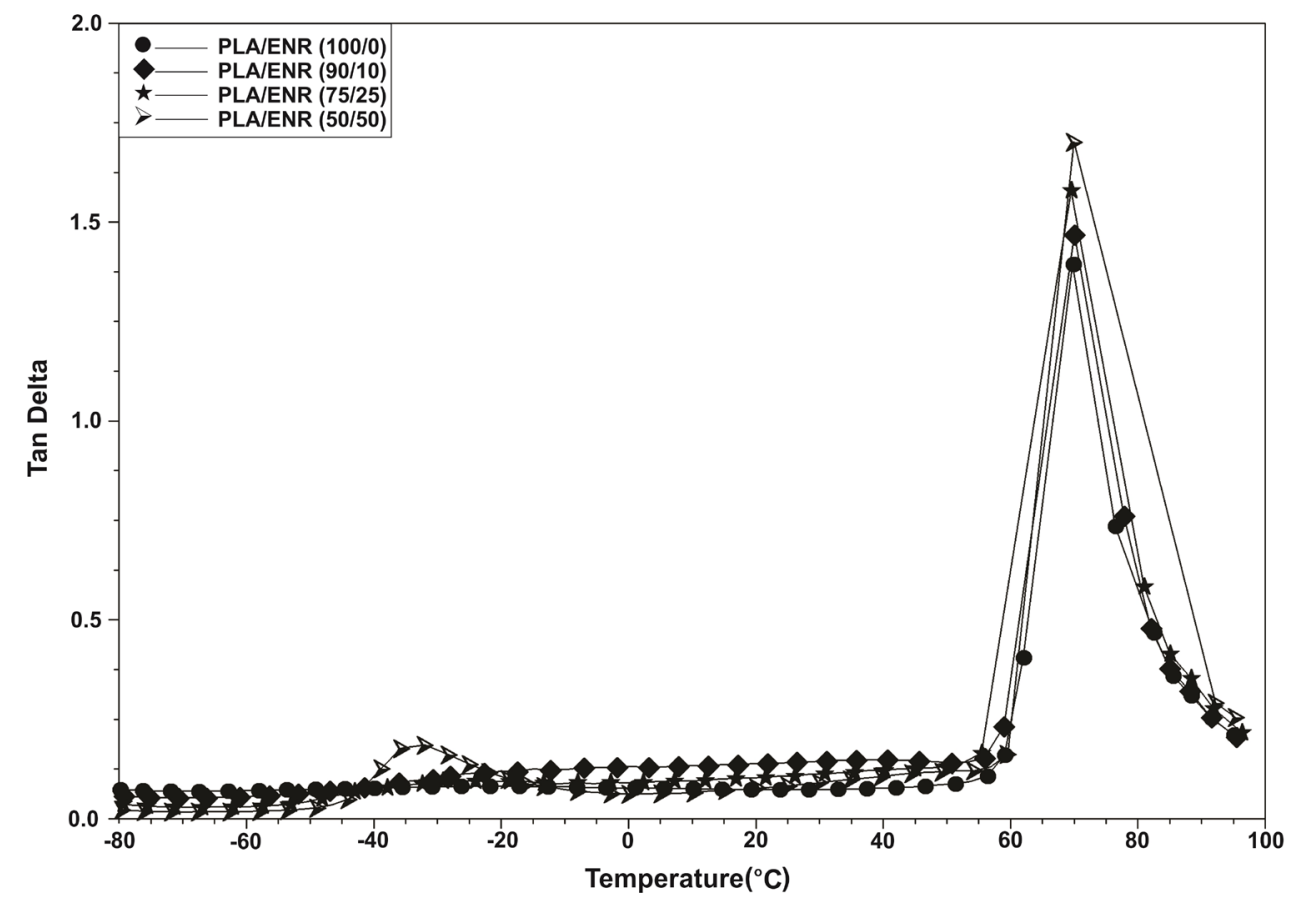

Figure 5. Tan $\delta$ curves versus temperature for PLA/ENR electrospun blends.

derived from renewable sources, the advantage of adding of ENR to PLA is reported. As consequences decrease the fiber diameter with enhancing the total surface area and porosity of mats and proportional increase in storage modulus over a usable temperature range is understood as interesting material for future applications.

\section{Acknowledgements}

The authors gratefully acknowledge the Brazilian Agencies CNPq (Grant No. 475533/2013-5), CAPES and FAPERJ (Grant No. E-26/110.895/2013) for supporting this work.

\section{References}

[1] Li, N., Qin, X.-H., Lin, L. and Wang, S.-Y. (2008) The Effects of Spinning Conditions on the Morphology of Electrospun Jet and Nonwoven Membrane. Polymer Engineering \& Science, 48, 2362-2366. http://dx.doi.org/10.1002/pen.21188

[2] Liu, H., Wang, S. and Qi, N. (2012) Controllable Structure Properties and Degradation of the Electrospun PLGA/PLABlended Nanofibrous Scaffolds. Journal of Applied Polymer Science, 125, E468-E473. http://dx.doi.org/10.1002/app.36757

[3] Kancheva, M., Toncheva, A., Manolova, N. and Rashkov, I. (2015) Enhancing the Mechanical Properties of Electrospun Polyester Mats by Heat Treatment. Express Polymer Letters, 9, 49-65. http://dx.doi.org/10.3144/expresspolymlett.2015.6

[4] Chew, S.Y., Wen, J., Yim, E.K.F. and Leong, K.W. (2005) Sustained Release of Proteins from Electrospun Biodegradable Fibers. Biomacromolecules, 6, 2017-2024. http://dx.doi.org/10.1021/bm0501149

[5] Agarwal, S., Wendorff, J.H. and Greiner, A. (2008) Use of Electrospinning Technique for Biomedical Applications. Polymer, 49, 5603-5621. http://dx.doi.org/10.1016/j.polymer.2008.09.014

[6] Kanani, A.G. and Bahrami, S.H. (2010) Review on Electrospun Nanofibers Scaffold and Biomedical Applications. Trends in Biomaterials and Artificial Organs: An International Journal, 24, 93-5621.

[7] Yang, F., Murugan, R., Wang, S. and Ramakrishna, S. (2005) Electrospinning of Nano/Microscale Poly(L-lactic acid) Aligned Fibers and Their Potential in Neural Tissue Engineering. Biomaterials, 26, 2603-2610. http://dx.doi.org/10.1016/j.biomaterials.2004.06.051

[8] Wang, X.Y., Drew, C., Lee, S.H., Senecal, K.J., Kumar, J. and Samuelson, L.A. (2002) Electrospun Nanofibrous 
Membranes for Highly Sensitive Optical Sensors. Nano Letters, 2, 1273-1275. http://dx.doi.org/10.1021/nl020216u

[9] Schreuder-Gibson, H., Gibson, P., Senecal, K., Sennett, M., Walker, J., Yeomans, W., Ziegler, D. and Tsai, P.P.J. (2002) Protective Textile Materials Based on Electrospun Nanofibers. Journal of Advanced Materials, 34, 44-55.

[10] Yun, K.M., Hogan, C.J., Matsubayashi, Y., Kawabe, M., Iskandar, F. and Okuyama, K. (2007) Nanoparticle Filtration by Electrospun Polymer Fibers. Chemical Engineering Science, 62, 4751-4759. http://dx.doi.org/10.1016/j.ces.2007.06.007

[11] Khil, M., Cha, D., Kim, H., Kim, I. and Bhattarai, N. (2003) Electrospun Nanofibrous Poly-Urethane Membrane as Wound Dressing. Journal of Biomedical Materials Research Part B: Applied Biomaterials, 67B, 675-679. http://dx.doi.org/10.1002/jbm.b.10058

[12] Kenawy, E.-R., Bowlin, G.L., Mansfield, K., Layman, J., Simpson, D.G., Sanders, E.H. and Wnek, G.E.J. (2002) Release of Tetracycline Hydrochloride from Electrospun Poly(ethylene-co-vinylacetate) Poly(lactic acid) and a Blend. Journal of Control Release, 81, 57-64. http://dx.doi.org/10.1016/S0168-3659(02)00041-X

[13] Casasola, R., Thomas, N.L., Trybala, A. and Georgiadou, S. (2014) Effect of Different Solvent Systems on Fibre Morphology and Diameter. Polymer, 55, 4728-4737. http://dx.doi.org/10.1016/j.polymer.2014.06.032

[14] Gaudio, C.D., Ercolani, E., Nanni, F. and Bianco, A. (2011) Assessment of Poly(e-caprolactone)/Poly(3-hydroxybutyrate-co-3-hydroxyvalerate) Blends Processed by Solvent Casting and Electrospinning. Materials Science and Engineering: A, 528, 1764-1772. http://dx.doi.org/10.1016/j.msea.2010.11.012

[15] Doshi, J. and Reneker, D.H.J. (1995) Electrospinning Process and Applications of Electrospun Fibers. Journal of Electrostatics, 35, 151-160. http://dx.doi.org/10.1016/0304-3886(95)00041-8

[16] Zakaria, Z., Islam, M.S., Hassan, A., Haafiz, M.K.M., Arjmandi, R., Inuwa, I.M. and Hasan, M. (2013) Mechanical Properties and Morphological Characterization of PLA/Chitosan/Epoxidized Natural Rubber Composites. Advances in Materials Science and Engineering, 2013, Article ID: 629092. http://dx.doi.org/10.1155/2013/629092

[17] Zhang, Q., Mochalin, V.N., Neitzel, I., Knoke, I.Y., Han, J., Klug, C.A., Zhou, J.G. and Lelkes, P.I. and Gogotsi, Y. (2011) Fluorescent PLLA-Nanodiamond Composites for Bone Tissue Engineering. Biomaterials, 32, 87-94. http://dx.doi.org/10.1016/j.biomaterials.2010.08.090

[18] Anaraki, N.A., Rad, L.R., Irani, M. and Haririan, I. (2015) Fabrication of PLA/PEG/MWCNT Electrospun Nanofibrous Scaffolds for Anticancer Drug Delivery. Journal of Applied Polymer Science, 132, 41286.

[19] Karuppuswamya, P., Venugopala, J.R., Navaneethana, B., Laivaa, A.L. and Ramakrishnaa, S. (2015) Polycaprolactone Nanofibers for the Controlled Release of Tetracycline Hydrochloride. Materials Letters, 141, 180-186. http://dx.doi.org/10.1016/j.matlet.2014.11.044

[20] Park, K., Kang, H.K., Lee, S.J., Min, B.M. and Park, W.H. (2006) Biomimetic Nanofibrous Scaffolds: Preparation and Characterization of PGA/Chitin Blend Nanofibers. Biomacromolecules, 7, 635-643. http://dx.doi.org/10.1021/bm0509265

[21] Hong, K.H., Woo, S.H. and Kang, T.J. (2012) In Vitro Degradation and Drug-Release Behavior of Electrospun Fibrous Webs of Poly(lactic-co-glycolic acid). Journal of Applied Polymer Science, 124, 209-214. http://dx.doi.org/10.1002/app.33357

[22] Davi, C.P., Galdino, L.F.M.D., Borelli, P., Oliveira Jr., O.N. and Ferreira, M. (2012) Natural Rubber Latex LbL Films: Characterization and Growth of Fibroblasts. Journal of Applied Polymer Science, 125, 2137-2147. http://dx.doi.org/10.1002/app.36309

[23] Costa, L.M.M., Mattoso, L.H.C. and Ferreira, M. (2013) Electrospinning of PCL/Natural Rubber Blends. Journal of Materials Science, 48, 8501-8508. http://dx.doi.org/10.1007/s10853-013-7667-0

[24] Cui, W., Li, X., Zhu, X., Yu, G., Zhou, S. and Weng, J. (2006) Investigation of Drug Release and Matrix Degradation of Electrospun Poly(DL-lactide) Fibers with Paracetamol Inoculation. Biomacromolecules, 7, 1623-1629. http://dx.doi.org/10.1021/bm060057z

[25] Kim, K., Yu, M., Zong, X., Chiu, J., Fang, D., Seo, Y.-S., Hsiao, B.S., Chu, B. and Hadjiargyrou, M. (2003) Control of Degradation Rate and Hydrophilicity in Electrospun Non-Woven Poly(DL-lactide) Nanofiber Scaffolds for Biomedical Applications. Biomaterials, 24, 4977-4985. http://dx.doi.org/10.1016/S0142-9612(03)00407-1

[26] Fernandes, R.M.B., Visconte, L.L.Y. and Nunes, R.C.R. (2011) Curing Characteristics and Aging Properties of Natural Rubber/Epoxidized Natural Rubber and Cellulose II. International Journal of Polymeric Materials and Polymeric Biomaterials, 60, 351-364. http://dx.doi.org/10.1080/00914037.2010.531806

[27] Zhang, C., Wang, W., Huang, Y., Pan, Y., Jiang, L., Dan, Y., Luo, Y. and Peng, Z. (2013) Thermal Mechanical and Rheological Properties of Polylactide Toughened by Expoxidized Natural Rubber. Materials and Design, 45, $198-205$. http://dx.doi.org/10.1016/j.matdes.2012.09.024

[28] Nghia, P.T., Siripitakchai, N., Klinklai, W., Saito, T., Yamamoto, Y. and Kawahara, S. (2008) Compatibility of Liquid 
Deproteinized Natural Rubber Having Epoxy Group (LEDPNR)/Poly(L-lactide) Blend. Journal of Applied Polymer Science, 108, 393-399. http://dx.doi.org/10.1002/app.27095

[29] Huang, Y., Zhang, C., Pan, Y., Zhou, Y., Jiang, L. and Dan, Y. (2013) Effect of NR on the Hydrolytic Degradation of PLA. Polymer Degradation and Stability, 9, 943-950. http://dx.doi.org/10.1016/j.polymdegradstab.2013.02.018

[30] Lim, L.T., Auras, R. and Rubino, M. (2008) Processing Technology for Poly(lactic acid). Progress in Polymer Science, 33, 820-852. http://dx.doi.org/10.1016/j.progpolymsci.2008.05.004

[31] Soheilmoghaddama, M., Wahitb, M.U. and Akos, N.I. (2013) Regenerated Cellulose/Epoxidized Natural Rubber Blend Film. Materials Letters, 111, 221-224. http://dx.doi.org/10.1016/j.matlet.2013.08.109

[32] Tham, W.L., Poh, B.T., Ishak, Z.A.M. and Chow, W.S. (2016) Epoxidized Natural Rubber Toughened Poly(lactic acid)/Halloysite Nanocomposites with High Activation Energy of Water Diffusion. Journal of Applied Polymer Science, 133, 42850. http://dx.doi.org/10.1002/app.42850

[33] Bitinis, N., Verdejo, R., Cassagnau, P. and Lopez-Manchado, M.A. (2011) Structure and Properties of Polylactide/Natural Rubber Blends. Materials Chemistry and Physics, 129, 823-831. http://dx.doi.org/10.1016/j.matchemphys.2011.05.016

[34] Picciani, P.H.S., Medeiros, E.S., Pan, Z., Wood, D.F., Orts, W.J., Mattoso, L.H.C. and Soares, B.G. (2010) Structural, Electrical, Mechanical, and Thermal Properties of Electrospun Poly(lactic acid)/Polyaniline Blend Fibers. Macromolecular Materials and Engineering, 295, 618-627. http://dx.doi.org/10.1002/mame.201000019

[35] Tham, W.L., Poh, B.T., Ishak, Z.A.M. and Chow, W.S. (2012) Crystallization Behavior of Poly(lactic acid)/Elastomer Blends. Journal of Polymer Research, 19, 9818-9830. http://dx.doi.org/10.1007/s10965-011-9818-9

[36] Suryanegara, L., Nakagaito, A.N. and Yano, H. (2009) The Effect of Crystallization of PLA on the Thermal and Mechanical Properties of Microfibrillated Cellulose-Reinforced PLA Composites. Composites Science and Technology, 69, 1187-1192. http://dx.doi.org/10.1016/j.compscitech.2009.02.022

[37] Wahit, M.U., Hassan, A., Ibrahim, A.N., Zawawi, N.A. and Kunasegeran, K. (2015) Mechanical, Thermal and Chemical Resistance of Epoxidized Natural Rubber Toughened Polylactic Acid Blends. Sains Malaysiana, 44, 1615-1623.

[38] Sarasua, J.-R., Prud’homme, R.E., Wisniewski, M., Le Borgne, A. and Spassky, N. (1998) Crystallization and Melting Behavior of Polylactides. Macromolecules, 3, 3895-3905. http://dx.doi.org/10.1021/ma971545p

[39] Chow, W.S. and Lok, S.K.J. (2008) Effect of EPM-g-MAH on the Flexural and Morphological Properties of Poly(lactic acid)/Organo-Montmorillonite Nanocomposites. Journal of Thermoplastic Composite Materials, 21, 265-277. http://dx.doi.org/10.1177/0892705708089477

[40] Goffin, A.-L., Raque, J.-M., Duquesne, E., Siqueira, G., Habibi, Y., Dufresne, A. and Dubois, P. (2011) From Interfacial Ring-Opening Polymerization to Melt Processing of Cellulose Nanowhisker-Filled Polylactide-Based Nanocomposites. Biomacromolecules, 12, 2456-2465. http://dx.doi.org/10.1021/bm200581h

[41] Kader, M.A., Kim, K., Lee, Y.-S. and Nah, C. (2006) Preparation and Properties of Nitrile Rubber/Montmorillonite Nanocomposites via Latex Blending. Journal of Materials Science, 41, 7341-7352. http://dx.doi.org/10.1007/s10853-006-0792-2 